\title{
Pensar e fazer a educação e formação humana em tempos de crise
}

1 Victor Hugo Nedel Oliveira victor.juventudes@gmail.com

1 Doutor em Educação. Licenciado e Mestre em Geografia. Professor do Departamento de Humanidades da Universidade Federal do Rio Grande do Sul - UFGRS

\section{RESENHA}

A obra apresenta, em dez capítulos, importantes e necessárias reflexões acerca do tema "Educação e Formação Humana" nos tempos contemporâneos de múltiplas crises pelos quais estamos vivendo. Tais crises repercutem na sociedade como um todo, o que não exclui os diferentes contextos educativos, e é para essas lentes que a proposta editorial da obra sugere mirar-se. Em quatro eixos-temáticos, os autores se dispõem a olhar os campos da educação e da formação em temáticas majoritariamente ligadas aos sistemas de ensino, à qualidade da educação escolar, à formação de professores e estudantes e aos processos relacionados nas múltiplas realidades sociais.

O primeiro eixo temático, de caráter mais introdutório, põe em tela a temática da formação humana e da educação, a partir da discussão de caminhos teóricos e metodológicos da pesquisa em educação. 0 segundo eixo traz à baila discussões atualizadas sobre as políticas educacionais, nas quais há o entendimento, dos autores, da necessidade de ampla defesa das políticas públicas para a educação, como potenciais mediadoras dos processos de humanização. 0 terceiro eixo, por sua vez, busca direcionar-se para as questões que dizem respeito às teorias e práticas das investigações no campo da educação, tensionado as possibilidades de produção de conhecimento nesse campo, como transformadores das práticas sociais dominantes. Por fim, um quarto eixo traz relatos de investigações que buscam apresentar a produção de conhecimento empírico nos campos abordados pelos eixos anteriores.

A diversidade de formação dos autores da obra possibilitou que se construísse um livro a partir de múltiplas possibilidades, potencialidades e intencionalidades analíticas, o que confere, por sua vez, riqueza conceitual à obra. 0 tema da formação humana a partir da leitura da educação configura-se em contexto de ampla relevância tanto na história da educação como na contemporaneidade, haja vista a constante necessidade de se pensar e praticar uma educação emancipadora e nos ajudar a responder as sempre contemporâneas dúvidas sobre a formação e a educação. Colocar essa discussão em pauta é um ato ousado que, por vezes, sente-se falta entre os pesquisadores do campo.

\section{REFERÊNCIA}

CARVALHO, Maria Vilani Cosme de; MARQUES, Eliana de Sousa Alencar; ARAUJO Francisco Antonio Machado (orgs.). Educação e formação humana: práticas de enfrentamento em tempos de crise. 1. ed. Teresina: EDUFPI, 2020.

\section{Como você deve citar?}

OLIVEIRA, Victor Hugo Nedel. Pensar e fazer a educação e formação humana em tempos de crise. Cadernos UniFOA, Volta Redonda, n. 44, p. xx-xx, dezembro 2020. 